\title{
EVEN THOUGH WE HAD MANY TRIBES, BUT I AM INDONESIA: VALIDATION OF DUAL IDENTITY SCALE
}

\author{
Muhammad Abdan Shadiqi ${ }^{1,2}$, Wildan Rusdaul Ulum ${ }^{1}$, Mirra Noor Milla ${ }^{1}$, \& Hamdi \\ Muluk $^{1}$
}

${ }^{1}$ Faculty of Psychology, Universitas Indonesia, Depok, Indonesia

UI Campus, Depok, Jawa Barat, Indonesia 16424

${ }^{2}$ Department of Psychology, Medical Faculty, Universitas Lambung Mangkurat, Banjarbaru, Indonesia

Jl. Veteran No. 128 Banjarmasin 70232 - Jl. A. Yani km 36,00 Banjarbaru 70712, Kalimantan Selatan, Indonesia

abdan.shadiqi@ulm.ac.id

\begin{abstract}
Dual identity has an assumption that subordinate group identity (e.g., ethnic and tribe identity) and superordinate group identity (e.g., national identity) can be simultaneously activated. The dual identity concept is important to examine in Indonesia as the country of thousands of tribes. As an initial step, we should adapt and evaluate a dual identity scale so that later it will become a catalyst for future study on the exploration of the association of dual identity and other factors. This study aims to adapt and evaluate the dual identity scale on the Indonesian sample. We tested the measurement through two collecting data, with 775 of total participants (data $1=338$ participants and data $2=473$ participants). The data were analyzed using exploratory factor analysis (EFA) and confirmatory factor analysis (CFA). We found that the dual identity scale had a good fit model and had satisfactory validity and reliability. The validity and reliability of data 2 are better than data 1 . In the data 2, each item of items used 'tribe' as a form of subordinate identity to replace 'ethnic' in the measurement of the data 1 . In data 1, this scale had a significant correlation with ethnic and national identity. The result of EFA and CFA proved that the scale is unidimensional (having one factor) and robust to use in the Indonesian sample. The study also found that the use of 'tribe' can explain subordinate identity better than "ethnic" on the scale. This study contributes to a practical implication for using the dual identity scale in Indonesia.
\end{abstract}

Keywords: dual identity; superordinate identity; subordinate identity; EFA; CFA

\begin{abstract}
Abstrak
Dual identity memiliki asumsi bahwa identitas subordinat kelompok (misal: identitas etnis, suku) dan identitas superordinat kelompok (misal: identitas nasional) dapat teraktivasi secara simultan. Konsep dual identity ini penting untuk dikaji di Indonesia sebagai negara dengan ribuan suku. Sebagai langkah awal, kita harus mengadaptasi dan mengevaluasi sebuah skala sehingga nanti menjadi katalisator untuk studi lebih lanjut yang mengeksplorasi kaitan dual identity dengan faktor lain. Studi ini bertujuan untuk mengadaptasi dan mengevaluasi skala dual identity pada sampel Indonesia. Kami menguji alat ukur pada dua pengambilan data yang berbeda dengan total 775 partisipan (data $1=338$ partisipan dan data $2=473$ partisipan). Data diuji menggunakan exploratory factor analysis (EFA) dan confirmatory factor analysis (CFA). Kami menemukan skala dual identity memiliki model yang fit, nilai validitas dan reliabilitas yang memuaskan. Nilai validitas dan reliabilitas alat ukur lebih baik pada data 2 dibandingkan data 1 . Pada data 2, item-item pernyataan menggunakan kata "suku" sebagai bentuk identitas subordinat untuk mengganti kata "etnis" pada pengukuran di data 1. Pada data 1, ditemukan alat ukur dual identity mempunyai hubungan yang signifikan dengan identitas etnis dan nasional. Hasil EFA dan CFA membuktikan bahwa skala memiliki 1 faktor atau unidimensional dan robust digunakan pada sampel Indonesia. Studi ini juga menemukan bahwa penggunaan kata "suku" dapat menjelaskan identitas subordinat lebih baik dibandingkan kata "etnis" pada skala. Studi ini memberikan implikasi praktis penggunaan skala dual identity di Indonesia.
\end{abstract}

Kata kunci: dual identity; identitas superordinat; identitas subordinat; EFA; CFA 


\section{INTRODUCTION}

Indonesia has 1,340 ethnic groups according to the data of the Population Census in 2010 (Badan Pusat Statistik (BPS), 2017). As a country full the diversity, the Indonesians had a motto 'Bhinneka Tunggal Ika' or unity in diversity, albeit it consists of tribes but remains as one Indonesian nation. Bhinneka Tunggal Ika is considered a concept and process history to compose 'identity blending' (Logli, 2015). Psychology explicated identity blending concept in terms of 'dual identity.' This identity concept has a way of working without eliminating the position of superordinate identity (e.g., national identity) when subordinate identity (e.g., ethnic and religious identity) appears (González \& Brown, 2003).

Some areas of psychological research increasingly utilized the dual identity concept (Fleischmann \& Verkuyten, 2016). Some psychology research popularly examined the dual identity concept through a quantitative approach (e.g., Martinovic \& Verkuyten, 2014; Shi, Dang, Zheng, \& Liu, 2017; Simon, Reichert, \& Grabow, 2013), albeit the other utilized a qualitative approach (e.g., Hopkins, 2011). Many studies applicated the dual identity concept on several topics, such as political movements (Martinovic \& Verkuyten, 2014), collective action (Ufkes, Calcagno, Glasford, \& Dovidio, 2016), social change (Simon et al., 2013), radical political action (Simon et al., 2013), political engagement (Fleischmann, Phalet, \& Swyngedouw, 2013), prejudice (Shi et al., 2017), intergroup bias (Banfield \& Dovidio, 2013), and school performance on minority group (Baysu, Phalet, \& Brown, 2011).

We did not find an empirical study that concretely explored the dual identity concept with other psychological constructs in the Indonesian context. However, Burhan and Sani (2013) examined the superordinate identity in the Indonesian sample. They studied how the national identity as superordinate identity explicated prejudice against ethnic Chinese (non-indigenous) in Medan among an indigenous ethnic Indonesian. Burhan and Sani found that national identity indirectly predicted prejudice, but the national identity significantly incremented prejudice through symbolic threat as a mediator factor. Though the dual identity might reduce prejudice (Shi et al., 2017). Shadiqi, Muluk, and Milla (2018) combined the measurement of two identities simultaneously in a correlational survey among Indonesian Muslim student activists, namely religious identity (as Muslim) and politicized identity (as activists) to explicate collective action to support Palestinian. They found that only politicized identity positively predicted collective action. Limitation from the study of Shadiqi et al. (2018) was not considering the utilize of dual identity concept, whereas another study with an experimental approach found that dual identity can reduce a person's motivation for social change as the aim of collective action (Glasford \& Dovidio, 2011).

With the incrementing psychological studies utilized dual identity concept, the more vigorously illustrated the requisite for robust measurement to capture the dual identity construct. The operationalization of the dual identity measurement was commenced by Benet-Martínez and Haritatos (2005), they constructed the coalescing concept on two cultural identities with the term the Bicultural Identity Integration (BII). Then this concept was developed into a dual identity measurement by Martinovic and Verkuyten (2014). Our study aims to adapt, test, and evaluate the dual identity measurement in the Indonesian context. We conducted this research because of the Indonesia condition with the diversity of tribal, the lack of studies on dual identity in Indonesia, and the incrementing number of dual identity studies in the world. We hope with the adaptation process of this measurement, the dual identity concept will be increasingly utilized to prove 
aspects of behavior, attitudes, feelings, and thoughts in the context of Indonesian society.

The dual identity theory was actually proposed as a response to the common ingroup identity model (CIIM) theory (Klandermans, 2015). Gaertner and Dovidio (2000), who developed the CIIM theory, expounded that to reduce the bias evaluation between groups, different members of the group are made inclusive by bringing up superordinate identities. However, the findings of Hornsey and Hogg (2000) contrast marginally with the CIIM explication, they explicated that common identity can pose a threat to subordinate identity and ultimately affect intergroup relations. This denotes that to maintain group relations or to obviate group conflict needed another identity mechanism to manage threats.

Then, the concept of dual identity emerged which was first coined by González and Brown (2003). They argued that when people identify with a subordinate group (e.g., ethnic identity) can simultaneously appear without eliminating a superordinate identity (e.g., national identity). According to González and Brown (2003), dual identity is a good thing because it can avert conflict with an individual's competency to identify two different subgroups. Simply, dual identity occurs when individuals can activate subordinate and superordinate identities at the same time. For example, when Javanese interacts with people from other countries, he/she will introduce himself as an Indonesian as well as a Javanese. This designates that Javanese-Indonesian identities appear without having to eliminate one of both identities.

According to Fleischmann and Verkuyten (2016), one form of dual identity measurement approach was to quantify two forms of identity discretely. The example of measurement on this approach was constructed by Fleischmann, Phalet, and Swyngedouw (2013). They measured national and ethnic identity discretely utilizing two measurements. In their study, Fleischmann et al. (2013) measured two kinds of other identities, namely the city and religious identities. There was another form of dual identity measurement approach, and this approach was developed from the BII model (Benet-Martínez \& Haritatos, 2005). The BII model proposed the measurement concept of two Chinese-American cultural identities using five items. Fleischmann and Verkuyten (2016) assess the BII model as one approach to investigate dual identity with the concept of mixed identity (blended identity). This model was characterized by the operationalization of subordinate and superordinate identities in each item of measurement item. From this BII model, Martinovic dan Verkuyten (2014) developed dual identity measurement on five items with good reliability (Alpha Cronbach alpha value of .80).

Martinovic and Verkuyten (2014) evaluated whether the scale has unidimensional (one factor) or multidimensional (two factors). They conceptualized the two factors with blended identity factor (Dual 1 and Dual 5) and situational factor (Dual 2, Dual 3, and Dual 4); see table 1 to find the five items. However, Martinovic and Verkuyten (2014) conclusively decided to analyze the dual identity scale utilizing one factor. Their decision was predicated on the value of validity obtained using one factor better than two factors. For this reason, our study aims to prove whether the dual identity scale of Martinovic and Verkuyten (2014) is more apt using one factor or two factors on the Indonesian sample.

In the original item, the 'Turkish-German' word is used as a subordinate group (BenetMartínez \& Haritatos, 2005). In our study, we utilized two specific terms to describe subordinate groups, namely 'ethnics' or 'etnis' in data 1 and 'tribes' or 'suku' in data 2. In Bahasa, the Indonesian researchers overlapped these two words because they are considered the same, for example, the study of Riyanti (2013) mentioned 'Etnis Jawa', while in the study of Alfian (2014) suggested 
'Suku Jawa'. Though these two words have different meanings, 'ethnic' is more commonly used to describe 'tribe.' Sangmpam (2017) expounded an example in Sub-Saharan Africa research, the use of the word 'tribe' has a negative connotation related to colonialism, researchers debated in the use of this term. Researchers in Africa prefer to use 'ethnic' rather than 'tribe.' For this reason, this study seeks to provide scientific evidence to clarify which words are better able to describe subordinate groups in Indonesia, whether 'ethnic" or 'tribe.'

Table 1.

Dual Identity Scale

\begin{tabular}{|c|c|c|}
\hline No & Code & Items \\
\hline 1 & Dual 1 & $\begin{array}{l}\text { I feel as [my tribe]-Indonesians } \\
\text { (Saya merasa sebagai orang [suku saya]-Indonesia) }\end{array}$ \\
\hline 2 & Dual 2 & $\begin{array}{l}\text { For me, it's easy to feel as an Indonesians in one situation and } \\
\text { as a [my tribe] people in another situation. } \\
\text { (Bagi saya, hal yang mudah merasa sebagai orang Indonesia } \\
\text { pada satu situasi dan sebagai orang [suku saya] pada situasi } \\
\text { lain) }\end{array}$ \\
\hline 3 & Dual 3 & $\begin{array}{l}\text { I feel at home with [my tribe] people and with Indonesians. } \\
\text { (Saya betah bersama dengan orang [suku saya] dan orang } \\
\text { Indonesia) }\end{array}$ \\
\hline 4 & Dual 4 & $\begin{array}{l}\text { I can really be myself among [my tribe] people and with } \\
\text { Indonesians. } \\
\text { (Saya dapat menjadi benar-benar diri sendiri di tengah-tengah } \\
\text { orang [suku saya] dan orang Indonesia) }\end{array}$ \\
\hline 5 & Dual 5 & $\begin{array}{l}\text { I feel like a both as Indonesians and [my tribe] people. } \\
\text { (Saya merasa sebagai orang Indonesia sekaligus orang [suku } \\
\text { saya]) }\end{array}$ \\
\hline
\end{tabular}

Notes: The five items were adapted in Bahasa. In data 1, the 'ethnic' or 'etnis' (in Bahasa) replace the 'tribe' or 'suku' (in Bahasa) for each item, for example, 'I feel as my ethnic-Indonesians.'

\section{METHOD}

\section{Participants}

This study consisted of two data collections. A total of 775 participants collected using convenience sampling techniques through online and paper-and-pencil surveys. The sample size in both data is adequate for Exploratory Factor Analysis (EFA) testing, which is above 200 participants (Izquierdo, Olea, \& Abad, 2014) or minimum ranges from 200 to 300 participants (Sakaluk \& Short, 2017). The sample size in data 1 and 2 have accepted the minimal sample size recommendation of the Confirmatory Factor Analysis (CFA) test which generally has a minimum number of 200 participants (Jackson, Voth, \& Frey, 2013) or range from 250 to 500 participants (Schumacker \& Lomax, 2016). Participants are Indonesian citizens over 17 years old. We did not only have a minimum target of getting group participants from the two most sizably voluminous tribes in Indonesia, namely Java and Sunda (BPS, 2017). Fortuitously we got participants from several tribes spread across Indonesia, such as Betawi, Minang, Malay, Banjar, and other tribes. This denotes that this study has sample representation from Java, Sumatra, and Kalimantan.

We collected 338 participants in data 1, the mean age was 24.97 years. Among the people who completed the survey, 211 were women $(62.4 \%)$ and 127 men (37.6\%). The sample consisted of 131 Javanese $(38.8 \%), 70$ Sundanese (20.7\%), 43 Banjarese (12.7\%), 31 Betawinese (9.2\%), 15 Minang people (4, $4 \%$ ), and several other tribes. The participants were 187 students (55.3\%), 87 employees 
$(25.7 \%), 31$ teachers $(9.17 \%)$ and several other jobs. All participants were Muslim.

In data 2, the sample consisted of 473 people (mean age was 24.87 years). There were 274 women (57.9\%) and 199 men $(42.1 \%)$. The sample consisted of 150 Javanese $(34.3 \%), 90$ Banjarese (20.6\%), 67 Sundanese (15.3\%), 32 Malay people (7.3\%), and several other tribes. The participants were 282 students $(64.5 \%)$, 40 employees (9.2\%), and several other jobs. Participants in the data 2 are 390 Muslims (89.2\%), 34 Protestant Christians (7.8\%), 33 Catholic (7.6\%), and several other religions.

\section{Procedure}

\section{The stage of measurement preparation}

Table 2.

The Ethnic/National Identity Measurement

\begin{tabular}{|c|c|c|}
\hline No & Code & Items \\
\hline 1 & $\begin{array}{l}\text { IdEth1 / } \\
\text { IdNas1 }\end{array}$ & $\begin{array}{l}\text { I identify strongly with my } \\
\text { ethnic group (Indonesians). } \\
\text { (Saya mengidentifikasi } \\
\text { secara kuat dengan } \\
\text { kelompok etnis saya } \\
\text { [kelompok orang Indonesia]) }\end{array}$ \\
\hline 2 & $\begin{array}{l}\text { IdEth2 / } \\
\text { IdNas2 }\end{array}$ & $\begin{array}{l}\text { I feel attached to my ethnic } \\
\text { group (Indonesians). } \\
\text { (Saya merasa lekat dengan } \\
\text { sesama kelompok etnis } \\
\text { [kelompok orang Indonesia]) }\end{array}$ \\
\hline 3 & $\begin{array}{l}\text { IdEth3 / } \\
\text { IdNas3 }\end{array}$ & $\begin{array}{l}\text { I am proud of my ethnic } \\
\text { group background } \\
\text { (Indonesians). } \\
\text { (Saya bangga dengan latar } \\
\text { belakang kelompok etnis } \\
\text { saya [kelompok orang } \\
\text { Indonesia]) }\end{array}$ \\
\hline 4 & $\begin{array}{l}\text { IdEth4 / } \\
\text { IdNas4 }\end{array}$ & $\begin{array}{l}\text { I feel connected to the people } \\
\text { from one group ethnic } \\
\text { (Indonesians). } \\
\text { (Saya merasa terhubung } \\
\text { dengan orang-orang dari } \\
\text { sesama kelompok etnis } \\
\text { [kelompok orang Indonesia]) }\end{array}$ \\
\hline
\end{tabular}

Notes: The four items were adapted in Bahasa. The phrase 'my ethnic group' refers to an ethnic identity measurement, and the phrase 'Indonesians' refers to a national identity measurement.

The researcher choses the dual identity scale through literature studies, and we decided to adapt the dual identity scale from Martinovic and Verkuyten (2014) and Benet-Martínez and Haritatos (2005). The instrument measured the concept of subordinate and superordinate identities at the same time (blended identities) in each item (see table 1). In addition, researchers also added and collected data 1 with measurements of ethnic identity and national identity, both of which were adapted from Martinovic and Verkuyten (2014) (see table 2). The ethnic and national identity measurement would be linked to the dual identity measurement to support the evaluation of the reliability measurement. Ethnic and national identity measurement have four items in each instrument.

\section{The Stage of Adaptation}

We conducted the independent translation method on the stages of the process of translating the measurement (Gudmundsson, 2009). Two independent or parallel translators translate the English or original version to the Bahasa version. Then we compared the consistency of the translation results through a third party (bilingual and understand the instrument content). The original measurement The original measurement was utilized in the context of the Netherlands and Germany, especially for Turkish immigrants (Martinovic \& Verkuyten, 2014). The research team synthesized the translated measurement. Then, a bilingual social psychologist reviewed the results of the synthesis. In the final version, we have adapted measurement in the Indonesian context. For example, the original item 'I feel Turkish-Dutch/TurkishGerman' was translated to 'Saya merasa sebagai orang Turki-Belanda/Turki-German' in Bahasa. Then it was synthesized to 'Saya merasa sebagai orang [etnis/suku saya]Indonesia' (I feel as [my tribe]-Indonesians).

We applied the use of the word 'ethnic' to the dual identity scale in data 1 . Then, after a statistical analysis of the measurement in data 1 , the researcher decided to try using the word 'tribe' in data 2 to replace the word 'ethnic' on each item. The word of '[My ethnic / 
tribe]' was utilized to facilitate the online survey collection without explicitly mentioning the name of a particular ethnic/tribe group in each item. We asked participants to identify their ethnicity at the beginning of the biodata. The answer ranged from 1 (strongly disagree) to 7 (strongly agree) ( 7 point-Likert scales). For details on instrument items, see tables 1 and 2.

\section{The Stage of Data Collecting}

The participant completed the self-reported through online and paper-and-pencil commences with the research information section, participation agreement (informed consent), demographical questions, and main measurement. In data 1, data was collected entirely online. While in data 2 , there were 98 people utilizing paper-and-pencil and 375 people utilizing online surveys. As a result of the initial screening, there was no missing value.

\section{Statistical Analysis Technique}

In the initial stage, we determined whether the dual identity scale was unidimensional or multidimensional, the researcher conducts the exploratory factor analysis (EFA) on SPSS. Then, we analyzed the confirmatory factor analysis (CFA) through Lisrel to confirm the measurement model. On the CFA, we assessed quality items according to Miles and Shevlin (1998) through standardized loading factor (SLF) value $(\geq .50)$. We evaluated convergent validity with Average Variance Extracted (AVE) value $(>.50)$ (Hair, Hult, Ringle, \& Sarstedt, 2014). To assess reliability, we utilized internal consistency with composite reliability (CR), this reliability criterion was more popular evaluated on Structural Equation Modeling (SEM) (Peterson \& Kim, 2013). Hair et al. (2014) explained that the satisfactory CR value ranged from .70 to .90 .

We evaluated the measurement model following criteria (Schumacker \& Lomax, 2016): (1) Chi Square $\left(\chi^{2}\right)$ is close to zero and $\mathrm{p}>.05$, (2) Goodness of Fit Index (GFI) is > .90, (3) Root Mean Square Error of
Approximation (RMSEA) is close to zero, or range from .05 to .08 . We also include Confidence Interval (CI) 90\% RMSEA value with lower CI close to 0 and upper CI less than .08 , (4) Comparative Fix Index (CFI) range from 0 (not fit) to 1 (perfect fit) or $>.90$.

\section{RESULTS AND DISCUSSION}

\section{Unidimensional Factor}

In the initial stage, we tested the exploratory factor analysis (EFA) on SPSS. Based on rotation orthogonal rotation (varimax) through Principal Component Analysis (PCA) in data $1(n=338)$ and data $2(n=473)$, we found that Kaiser-Meyer-Olkin (KMO) value was .826 and .864 . Value of Bartlett's Test of Sphericity in data 1 was $X^{2}(10)=$ $551.283, \mathrm{p}<.001$ and data 2 was $X^{2}(10)=$ $1442.082, \mathrm{p}<.001$. KMO value $(>.50)$ and Bartlett $(\mathrm{p}<.05)$ demonstrated that the sample size of data 1 and 2 was adequate for the interpretation of EFA test results. The score of total initial eigenvalues in data 1 and 2 indicated that there was one component factor with a value $>1$. This result denoted that the measurement has one factor (unidimensional).

EFA results in the initial test indicated that dual identity has one factor (unidimensional). This finding confirmed the results of Martinovic and Verkuyten study (2014), they decided to use one factor. Benet-Martínez and Haritatos (2005); Fleischmann and Verkuyten (2016) explained that there was one approach to measuring dual identity utilizing the concept of blended identity. In our study, this concept was illustrated in each item with containing the words 'my ethnic/my tribe' and 'Indonesians'. For example, if the participant is Javanese, he or she inclines to feel Javanese-Indonesian when answering item 1 on the dual identity scale. Item 1 (Dual 1) is an example of the operationalization of a blended identity. This construct consisted of subordinate identity (ethnic: Javanese) and superordinate identity (national: Indonesian). The construct also applies to the other four items. 


\section{Normality Test}

Before we analyzed the data using CFA, we checked the normality distribution of the data. The results of multivariate normality and univariate normality tests in Lisrel indicated non-normality distribution in data 1 and 2 (p $>$.05). According to Shi, Lee, and MaydeuOlivares (2019), the normality assumption was generally not met in many tests. One solution to overcome the non-normality distribution of data was to use robust maximum likelihood (RML) methods ( $\mathrm{Li}$, 2016). We corrected the data using the asymptotic covariance matrix, and this method was the most straightforward alternative to overcome this problem through RML estimation. In this study, researchers decided to use RML to estimate CFA while maintaining the amount of research data.

\section{Data 1: CFA test and Relationship Dual, Ethnic, and National Identity}

In the method section, the dual identity scale in data $1(n=338)$ utilized the specific word 'Ethnic' to indicate the subordinate group. We tested CFA without modification of the model measurement structure. SLF scores ranged from .62 to .74, and it means that all items have a satisfactory SLF score $(>.50) . R^{2}$ value of all items ranged from $.385-.619$. CR value was satisfactory with .822 . Meanwhile, the convergent validity value (AVE) was .483. Albeit the AVE value was below .50, Fornell and Larcker (1981) expounded that it was no problem with the validity of the measurement if the AVE value was less than .50, provided the reliability value was above .60 . Measurement model indicated the criteria of a model good fit, $\chi^{2}=7.96, \mathrm{df}=5, p=.159$, $\mathrm{GFI}=.979, \mathrm{CFI}=.996, \mathrm{RMSEA}=.042,90 \%$ CI For RMSEA $=.000, .094$. For details about the comparison of the CFA results in data 1 and 2 can be seen in table 4 . While the results of the path diagram analysis can be seen in Figure 1.

Then, researchers also calculate the regression analysis and found that there was a significant relationship between dual identity with ethnic identity $(\beta=.696, S E=.078, t=$ $\left.8.906, p<.05, R^{2}=.485\right)$ and national identity $\left(\beta=.678, S E=.086, t=7.904, p<.05, R^{2}=\right.$ .459 ) (see figure 2 ). This finding also explained that the regression coefficient and the $\mathrm{R}^{2}$ value of the relationship between dual identity and ethnic and national identity was not much different. In the regression model (see figure 2), we also found that the SLF of statement items on ethnic identity measurement ranged from .75 to .84 . The ethnic identity measurement had good reliability $(\mathrm{CR}=.875)$ and good convergent validity $(\mathrm{AVE}=.687)$. The national identity measurement had a satisfy SLF (.79-.91), very good reliability $(\mathrm{CR}=.911)$, and good convergent validity $(\mathrm{AVE}=.742)$. Both of ethnic and national identity measurements had satisfied validity and reliability.

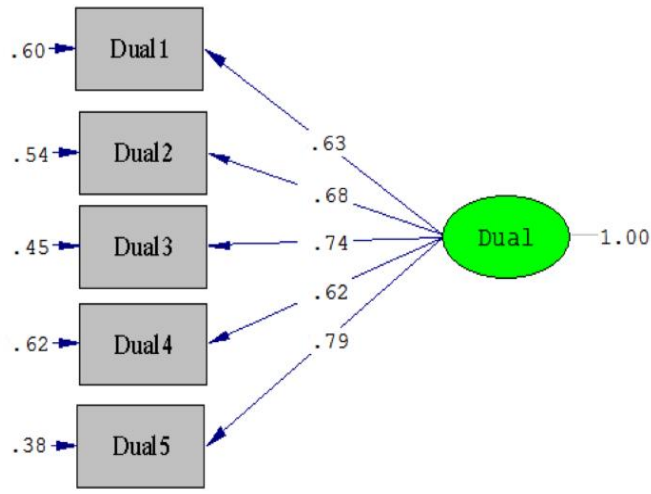

Chi-Square=7.96, df=5, P-value $=.15855, \mathrm{RMSEA}=.042$

Figure 1. The result of CFA test on Data $(\mathrm{n}=$ 338), Dual= Dual identity

In data 1 , we found that the coefficient regression of the correlation between dual identity with ethnic identity and dual identity with national identity was proximately similar. Dual identity has a significant positive relationship with ethnic and national identity. Two things can expound in these findings. First, dual identity has good reliability. The reliability technique referred to in this explication is the parallel-form or equivalent reliability technique (Bolarinwa, 2015). This reliability was evaluated by applying two different instruments and giving it to one sample group (Barry, Chaney, 
Piazza-Gardner, \& Chavarria, 2014). We evaluated parallel reliability with correlation analysis. In data 1 , dual identity correlated significantly with ethnic and national identity (see figure 2 and table 3 ).

Second, these findings indicated that Indonesians are more likely to place ethnic immigrants in the Netherlands who come from Afghanistan, Iran, Iraq, and Somalia were more likely to feel as Dutch (national identity) when a dual identity was measured. Immigrants in the Netherlands abandoned their ethnic identity when there was a dual identity more salient. Other our findings found that ethnic identity was and national identities as equals. This finding was different from Study 1 of Fleischmann and Verkuyten (2016), which proves that immigrants in the Netherlands who come from Afghanistan, Iran, Iraq, and Somalia were more likely to feel as Dutch (national identity) when a dual identity was measured. Immigrants in the Netherlands abandoned their ethnic identity when there was a dual identity more salient. Other our findings found that ethnic identity was positively correlated with national identity, this finding is in line with the results of Suryani, Setiadi, Nurrachman, Panggabean, and Wibawa (2019). The study of Suryani et al. (2019) found that the ethnic identity of Jakarta people from Chinese and non-Chinese ethnic samples was positively related to the national identity as Indonesian people. Our other findings also explained that ethnic identity has a stronger relationship with dual identity than national identity. The reason for this finding is because Indonesia, as a multicultural country, was taught to live together in diversity without losing each other's identities (Brata, 2016).

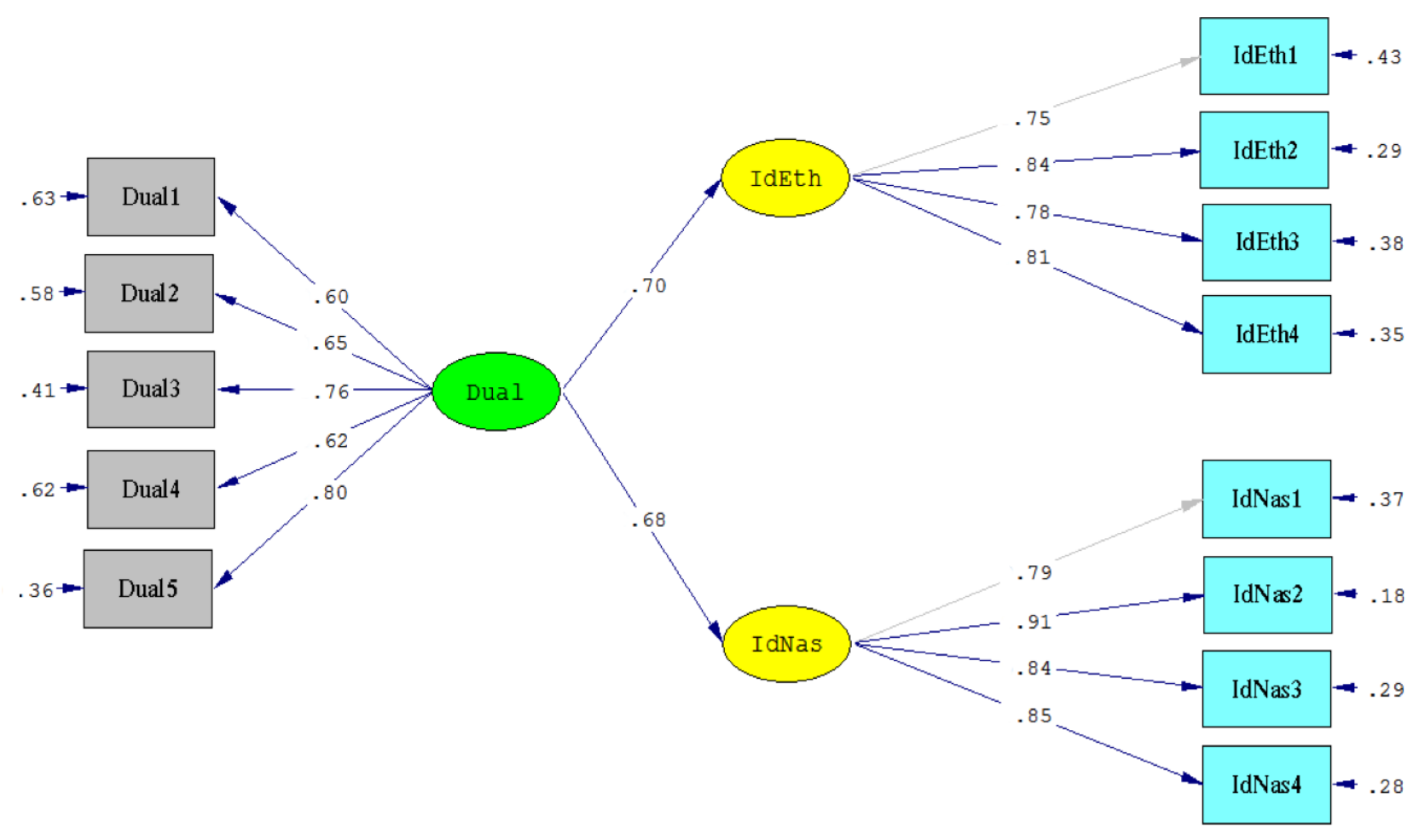

Chi-Square=137.43, df=63, $\mathrm{P}-$ value $=.00000, \mathrm{RMSEA}=.059$

Figure 2. Regression Analysis between Dual Identity (Dual), Ethnic Identity (IdEth) and National Identity (IdNas) 
Table 3.

The Correlation and Descriptive Statistic on Data $1(n=338)$

\begin{tabular}{llllll}
\hline & Mean & SD & 1 & 2 & 3 \\
\hline 1. Dual identity & 5.635 & 1.049 & - & $.580^{* *}$ & $.552^{* *}$ \\
2. Ethnic identity & 5.078 & 1.241 & & - & $.492^{* *}$ \\
3. National identity & 5.715 & 1.056 & & & - \\
\hline \multicolumn{2}{c}{ Notes: SD= Standard Deviation, ${ }^{* *} \mathrm{p}<.001$} & &
\end{tabular}

Table 4.

Comparison of SLF, CR, and Goodness of Fit between Data 1 and Data 2

\begin{tabular}{|c|c|c|c|}
\hline & & Data $1(n=338)$ & Data $2(n=473)$ \\
\hline \multicolumn{4}{|l|}{ SLF } \\
\hline 1. & Item 1 & .63 & .73 \\
\hline 2. & Item 2 & .68 & .64 \\
\hline 3. & Item 3 & .74 & .91 \\
\hline 4. & Item 4 & .62 & .83 \\
\hline & Item 5 & .79 & .86 \\
\hline $\mathrm{CR}$ & & .822 & .897 \\
\hline AVE & & .483 & .640 \\
\hline$\chi^{2}$ & & $7.96(d f=5, p=.159)$ & $12.834(d f=5, p=.025)$ \\
\hline GFI & & .979 & .978 \\
\hline RMSEA & & $\begin{array}{l}.042(\mathrm{CL} 90 \% \text { RMSEA }=.000 \text {; } \\
.094)\end{array}$ & $\begin{array}{l}.058 \text { (CL 90\% RMSEA= .019; } \\
, 098)\end{array}$ \\
\hline CFI & & .996 & .996 \\
\hline
\end{tabular}

\section{Data 2: CFA Test}

Data 2 specifically utilized the word 'tribe' to replace the word 'ethnic' (see table 1). The result of the CFA analysis on Data 2 found a satisfy SLF score $(.73-.91)$ (see figure 3 ). This SLF score was higher than the results of the CFA analysis in data 1 . The $\mathrm{R} 2$ value of all items ranged from .404 to .825 . The CR value indicated .897, which was slightly higher than the CFA 1 data model. The AVE value showed good convergent validity at .640. In data 2, the CFA model was good fit with $\mathrm{GFI}=.978, \mathrm{CFI}=.996, \mathrm{RMSEA}=.058$, $90 \%$ CI For RMSEA $=.019, .098$. Meanwhile the score $\chi^{2}=12.834, \mathrm{df}=5, \mathrm{p}=.025$ was not sufficiently meet the fit criteria, the significance value of chi-square was $>.01$, different from data 1 with the p-value $>.05$. Chi-square value can depend on sample size, the larger the sample size, the higher the chisquare value. In conclusion, chi-square does not support the model fit index on the sample size of this study. Like data 1, we tested CFA analysis without any modification of the structural model of the quantifying instrument.
Through the EFA and CFA analysis, we found that the dual identity scale has good validity and reliability. Our measurement also indicated good internal consistency reliability. In the data 1 , we found that the dual identity scale was quite equivalent to the measurement of ethnic and national identity.

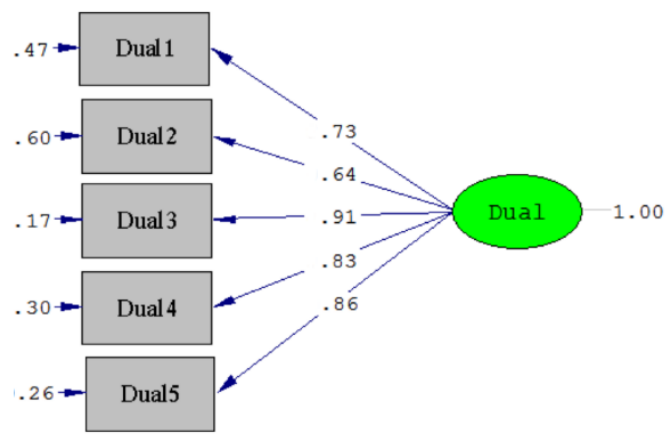

Chi-Square $=12.83, \mathrm{df}=5, \mathrm{P}-\mathrm{value}=.02498, \mathrm{RMSEA}=.058$

Figure 3. CFA Result in Data $2(n=473)$, Dual= Dual identity

In line with the EFA results, this study found that the measurement model with 1 factor had a fit model in the CFA test. The measurement model of data 1 was more fit than data 2 , albeit both data have a good fit on several criteria of goodness of fit. The CFA test 
results additionally showed that the items have satisfactory validity. Likewise, the reliability value also showed satisfying quality. These findings confirmed that the dual identity scale was more suitable to use 1 factor consisting of 5 items statement.

Data 1 and 2 have differences in the sample size and also the use of specific words ('tribe' and 'ethnic') that refer to subordinate identity. Principally, both data 1 and 2 have a good fit model, although data 1 is more fit than data 2 (see table 4). However, if we saw from the value of validity (AVE of data $2=.640, \mathrm{AVE}$ of data $1=.483$ ) and reliability (CR of data $1=.897, \mathrm{CR}$ of data $2=.822$ ), then data 2 has a more satisfying than data 1 . This finding illustrated that the utilize of the word 'tribe' (or 'suku' in Bahasa) was more accepted by a member of the tribe group to describe the subordinate identity of Indonesian, for example, Javanese, Sundanese, and Banjarese. This was different from the explanation of Sangmpam (2017) which explained that researchers in African studies utilize the word 'ethnic' to replace the word 'tribe'.

We have a unique finding that in Indonesia, the word 'tribe' was better able to explain subordinate identity. BPS (2017) defined the group tribe as people (nations) who have a common identity in culture, language, and regional origin. We argued that the word 'tribe' created the social identity of subordinate groups in Indonesia more salience or perceived closeness to the person than to the word 'ethnic.' People internalize group membership and make comparisons between groups more salience to achieve a more positive social identity (Ellemers \& Haslam, 2012).

This study has limitations in the diversity of the group samples. As expounded earlier in the background, Indonesia has thousands of tribes and tens of thousands of islands. There was an unequal comparison of the number and distribution of tribe in the sample of our study. Tribal representation was dominated by three islands (Java, Sumatra, and Kalimantan). Besides, we withal did not conduct a more indepth analysis of the differences in the participant's residence, for example, urban and rural. Through comparisons between different groups, future studies can consider to utilize measurement invariance analysis to evaluate the quality of the instrument in different sample groups (van de Schoot, Lugtig, \& Hox, 2012). In the last limitation, the dominance of the participants of this study were students, and the future researcher should consider generalizing of research results on other job criteria.

There were two suggestions to achieve generalization of measurements and to examine the relationship of dual identity with other psychological constructs. The first suggestion, further research can focus on developing measurement by considering variations in other types of subordinate identity, for example, religious, immigrant, minority, and different kinds of groups. The next study should use a specific word to represent the identity of certain subordinate groups according to the criteria of the target participants.

In the second suggestion, after we have a robust measurement, the next study could test the relationship of dual identity with other psychological variables. The other researchers should consider exploring the value of nationalism and the intergroup relation among various ethnic. Besides research topics, future researchers should choose methods to examine the relationship of dual identity with other variables. The Indonesian researchers potentially discover the novelty findings and confirm previous findings outside Indonesia. Other studies replicate the previous studies, for example, conducting an experimental replication study (Shadiqi, Muluk, \& Milla, 2019).

\section{CONCLUSION}

This study adapted and evaluated a dual identity scale with Indonesian sample. 
Through the results of EFA and CFA analysis illustrated that the concept of dual identity is more suitable to use 1 factor (unidimensional) in the Indonesia sample. National and ethnic/tribal identities were easier to merge into a unity (identity blending) following the slogan 'Bhineka Tunggal Ika' which has been embedded since the Indonesian state was founded. Based on the evaluation results of the instrument, we suggest that in utilizing a dual identity scale with the word 'tribe' rather than 'ethnic' to represent subordinate groups in Indonesian. Our study indicated that the quality of measurement was good validity and reliability consistently in two different collected data. This study also showed that the utilize of a specific word to show subordinate identity determined the quality of the instrument.

\section{ACKNOWLEDGMENTS}

This research was presented at the 13th HIMPSI Congress in Bandung-2018, the authors were grateful for the input and questions during the scientific meeting. The author also thanks the translators and social psychologists who helped in the adaptation process. This research is one part of the research grant of Program Magister Menuju Doktoral untuk Sarjana Unggulan (PMDSU) in 2018 from the Indonesian Ministry of Research and Technology. The author also thanks to the research funding.

\section{REFERENCES}

Alfian, M. (2014). Regulasi emosi pada mahasiswa suku Jawa, suku Banjar, dan suku Bima. Jurnal Ilmiah Psikologi Terapan, 2(2), 263-275.

Badan Pusat Statistik (BPS). (2017). Statistik Politik 2017. Jakarta, Indonesia: Badan Pusat Statistik (BPS-Statistik Indonesia).

Banfield, J. C., \& Dovidio, J. F. (2013). Whites' perceptions of discrimination against Blacks: The influence of common identity. Journal of
Experimental Social Psychology, 49(5), 833-841.

doi:10.1016/j.jesp.2013.04.008.

Barry, A. E., Chaney, B., Piazza-Gardner, A. K., \& Chavarria, E. A. (2014). Validity and reliability reporting practices in the field of health education and behavior: A review of seven journals. Health Education and Behavior, 41(1), 12-18. doi:10.1177/1090198113483139.

Baysu, G., Phalet, K., \& Brown, R. (2011). Dual identity as a two-edged sword: Identity threat and minority school performance. Social Psychology Quarterly, 74(2), 121-143. doi:10.1177/0190272511407619.

Benet-Martínez, V., \& Haritatos, J. (2005). Biculturol Identity Integration (BII): Components and psychosocial antecedents. Journal of Personality, 73(4), 1015-1049. doi:10.1111/j.14676494.2005.00337.x.

Bolarinwa, O. (2015). Principles and methods of validity and reliability testing of questionnaires used in social and health science researches. Nigerian Postgraduate Medical Journal, 22(4), 195. doi:10.4103/1117-1936.173959.

Brata, I. B. (2016). Kearifan budaya lokal perekat identitas bangsa. Jurnal Bakti Saraswati, 5(1), 9-16.

Burhan, O. K., \& Sani, J. (2013). Prejudice towards chinese ethnic group in medan: The roles of national identity and perceived threats. Psikologia, 8(1), 25$33 . \quad$ Retrieved from https://jurnal.usu.ac.id/index.php/psikol ogia/article/download/6599/2757

Ellemers, N., \& Haslam, S. A. (2012). Handbook of theories of social psychology. London: Sage.

Fleischmann, F., Phalet, K., \& Swyngedouw, M. (2013). Dual identity under threat: 
When and how do turkish and moroccan minorities engage in politics? Zeitschrift Fur Psychologie / Journal of Psychology, 221(4), 214-222. doi:10.1027/2151-2604/a000151.

Fleischmann, F., \& Verkuyten, M. (2016). Dual identity among immigrants: Comparing different conceptualizations, their measurements, and implications. Cultural Diversity and Ethnic Minority Psychology, 22(2), 151-165. doi:10.1037/cdp0000058.

Fornell, C., \& Larcker, D. F. (1981). Evaluating structural equation models with unobservable variables and measurement error. JMR, Journal of Marketing Research, 18(1), 39-50.

Gaertner, S. L., \& Dovidio, J. F. (2000). Reducing intergroup bias: The common ingroup identity model. New York, NY, US: Psychology Press.

Glasford, D. E., \& Dovidio, J. F. (2011). E pluribus unum: Dual identity and minority group members' motivation to engage in contact, as well as social change. Journal of Experimental Social Psychology, 47(5), 1021-1024. doi:10.1016/j.jesp.2011.03.021.

González, R., \& Brown, R. (2003). Generalization of positive attitude as a function of subgroup and superordinate group identifications in intergroup contact. European Journal of Social Psychology, 33(2), 195-214. doi:10.1002/ejsp.140.

Gudmundsson, E. (2009). Guidelines for translating and adapting psychological instruments. Nordic Psychology, 61(2), 29-45. doi:10.1027/1901-2276.61.2.29.

Hair, J. F., Hult, G. T. M., Ringle, C. M., \& Sarstedt, M. (2014). A prime on Partial Least Squares Structural Equation Modeling (PLS-SEM). California, USA: Sage Publications.
Hopkins, N. (2011). Dual identities and their recognition: Minority group members' perspectives. Political Psychology, 32(2), 251-270. doi:10.1111/j.14679221.2010.00804.x

Hornsey, M. J., \& Hogg, M. A. (2000). Assimilation and diversity: An integrative model of subgroup relations. Personality and Social Psychology Review, 4(2), 143-156. doi:10.1207/s15327957pspr0402_03.

Izquierdo, I., Olea, J., \& Abad, F. J. (2014). Exploratory factor analysis in validation studies: Uses and recommendations. Psicothema, 26(3), 395-400. doi:10.7334/psicothema2013.349.

Jackson, D. L., Voth, J., \& Frey, M. P. (2013). A note on sample size and solution propriety for confirmatory factor analytic models. Structural Equation Modeling, 20(1), 86-97. doi:10.1080/10705511.2013.742388.

Klandermans, B. (2015). Collective Action. In A. R. Oberschall (Ed.). International Encyclopedia of Social \& Behavioral Sciences, (4), 145-150. Doi:10.1016/B978-0-08-0970868.24001-4.

Li, C. H. (2016). Confirmatory factor analysis with ordinal data: Comparing robust maximum likelihood and diagonally weighted least squares. Behavior Research Methods, 48(3), 936-949. doi:10.3758/s13428-015-0619-7.

Logli, C. (2015). Bhinneka Tunggal Ika (Unity in Diversity): Nationalism, Ethnicity, and Religion in Indonesian Higher Education. Dissertation Publication. United Stated: University of Hawai'i At Manoa.

Martinovic, B., \& Verkuyten, M. (2014). The political downside of dual identity: Group identifications and religious political mobilization of Muslim 
minorities. British Journal of Social Psychology, 53, 711-730. doi:10.1111/bjso.12065

Peterson, R. A., \& Kim, Y. (2013). On the relationship between coefficient alpha and composite reliability. Journal of Applied Psychology, 98(1), 194-198. https://doi.org/10.1037/a0030767

Riyanti, P. (2013). Relasi sosial pedagang etnis Cina dan Etnis Jawa di pasar tradisional. Komunitas, 5(1), 53-63. doi: 10.15294/komunitas.v5i1.2373.

Sakaluk, J. K., \& Short, S. D. (2017). A methodological review of Exploratory Factor Analysis in sexuality research: Used practices, best practices, and data analysis resources. Journal of Sex Research, 54(1), 1-9. doi:10.1080/00224499.2015.1137538

Sangmpam, S. N. (2017). Ethnicities and tribes in Sub-Saharan Africa: Opening old wounds. Springer.

Schumacker, R. E., \& Lomax, R. G. (2016). $A$ Beginner's guide to structural equation modeling. New York: Routledge.

Shadiqi, M. A., Muluk, H., \& Milla, M. N. (2018). Palestinian solidarity action: The dynamics of politicized and religious identity patterns among student activists. Makara Human Behavior Studies in Asia, 22(2), 118-128. doi:10.7454/hubs.asia.1140818

Shadiqi, M. A., Muluk, H., \& Milla, M. N. (2019). Experiment replication: A proposed solution for developing psychological research in Indonesia. Anima Indonesian Psychological Journal, 33(4), 213-230. doi:10.24123/aipj.v33i4.1795

Shevlin, M., \& Miles, J. N. (1998). Effects of sample size, model specification and factor loadings on the GFI in confirmatory factor analysis. Personality and Individual Differences, 25, 85-90. doi:10.1.1.569.4650

Shi, D., Lee, T., \& Maydeu-Olivares, A. (2019). Understanding the model size effect on SEM fit indices. Educational and Psychological Measurement, 79(2), 310-334.

doi: $10.1177 / 0013164418783530$

Shi, Y., Dang, J., Zheng, W., \& Liu, L. (2017). Dual identity and prejudice: The moderating role of group boundary permeability. Frontiers in Psychology, 8 (FEB), $1-9$. doi:10.3389/fpsyg.2017.00195

Simon, B., Reichert, F., \& Grabow, O. (2013). When dual identity becomes a liability: Identity and political radicalism among migrants. Psychological Science, 24(3), 251-257.

doi:10.1177/0956797612450889

Suryani, A., Setiadi, B., Nurrachman, N., Panggabean, H., \& Wibawa, D. S. (2019). National identity as predicted by ethnic identity and social distance with multiculturalism as mediator: A study Involving chinese Indonesian students in Jakarta. Makara Human Behavior Studies in Asia, 23(2), 172-180. doi:10.7454/hubs.asia.1170719

Ufkes, E. G., Calcagno, J., Glasford, D. E., \& Dovidio, J. F. (2016). Understanding how common ingroup identity undermines collective action among disadvantaged-group members. Journal of Experimental Social Psychology, 63, 26-35. doi:10.1016/j.jesp.2015.11.006

Van de Schoot, R., Lugtig, P., \& Hox, J. (2012). A checklist for testing measurement invariance. European Journal of Developmental Psychology, 9(4), $\quad$ 486-492. doi:10.1080/17405629.2012.686740 